\title{
Toward a bioethical perspective for posthumanist aesthetics: Bioart as an example
}

\author{
BOGUMIŁA SUWARA
}

DOI: https://doi.org/10.31577/WLS.2021.13.1.7

To be or not to be genetically modified?

Francesca Ferrando $(2019,127)$

Should there be limits to what artists may do with biological materials in the name of art? These questions require reflecting upon the tensions between the values of "free expression" typically extended to art and artists, and ethical limits that have emerged in the biosciences due to some noteworthy failings of scientists in the past.

David Koepsell (2017, 71)

Rapid technological development has provoked fears regarding the safety of technological applications. ${ }^{*}$ In the field of information and cultural technologies, access to the text generator GPT2-AI (for the creation of news reports or fiction) was recently discontinued due to fears of potential abuse (Rosenberg 2017; Hern 2019). Bioethicists earlier pointed out the potential risks stemming from biotechnology (Bostrom 2002). In publications dealing with these issues, the warning of Jeremy Lanier was often repeated as to whether one should do all that one could (Vaage 2016a), but after the most recent development in gene editing (CRISPR-Cas9) was introduced to clinical practice, it became necessary to reformulate this issue in order to make this introduction as careful and safe as possible (Sýkora 2019).

The influence of information technology and biotechnology on the transformation of Homo sapiens in the direction of a hypothetical posthuman person (Huxley 1957; Bostrom 2008) or being has been postulated by members of the transhumanist movement, which today is chiefly represented by the +HUMAN organization. Some authors (e.g., Hayles 2011) have expressed doubts over the overly optimistic promises of information technology regarding its ability to transform the human consciousness into artificial intelligence (AI). Furthermore, as biotechnology allows for the possibility of modifying the genetic line of Homo sapiens, bioethicists warn that futuristic transhumanist visions have to be taken seriously and discussed in the present (Porter 2017; Sorgner 2010).

Transhumanist visions were nourishment for the popular imagination, especially in the 1990s (Bolter 2016; Troffoletti 2007). Bioartists have used biotechnology

* This article was supported by the project APVV-17-0064 "Analysis of multidimensional forms of trans- and post-humanism". 
and living organisms continually since the 1980s, but "transhumanist art" posited within transhumanism (Vita-More 2018; Bostrom 2008) has not managed to penetrate much into the art world or establish itself there. For this reason, artworks that experiment with biotechnology are created and interpreted chiefly within the context of the posthumanist intellectual mainstream (Simoniti 2019) or in posthuman aesthetics (Ferrando 2016 and 2019). The goal of this study is to explore to what extent and under what conditions bioethics can, as a careful overseer, penetrate into the space of posthuman aesthetics, including the use of DIY strategies as a mode of transfer of scientific and technological knowledge to the general public and their participation in deciding on the future of the genome, and consequently of Homo sapiens as such. It does this using the example of bioart, which has expressed itself through biotechnology.

\section{THE POSTHUMANIZED SOCIETY AND QUESTIONS OF BIOETHICS}

The posthumanized society is most commonly presented as an imagined future where human beings are more "computerized", becoming further and further integrated into artificial devices and systems, and computers are more "humanized", especially in terms of acquiring social, emotional, and learning abilities (Gladden 2019). In this process of social transformation, one will be able to witness the creation of highly sophisticated social and emotional robots, embodied AI, artificial life, self-organizing and self-directing computer networks, avatars in virtual worlds, and other artificial forms of intelligent cyber-physical social agents (Gladden 2019). In this vision, the development of the "natural human" is given only a modest role; in Gladden's categories, this would be the "meta-human" as a genetically improved society of Homo sapiens.

Peter Sýkora (2019) recently pointed out the need to re-evaluate the underappreciated significance of potential biological changes shifting toward a posthuman population. Sýkora argues that "we can expect the creation of a posthuman being from directed genetic engineering, the field of biology, rather than the uploading of minds into non-biological media, as suggested in information and communication technologies, and therefore it [...] is of great importance to direct the attention of posthumanist discourse in this direction" (513). This position is based on an interpretation of the long-term results of processes of gene-editing technology as well as the reaction of experts to the first clinical application of CRISPER-Cas9 technology for human genome modification by the Chinese scientist He Jiankui. Experts called this clinical use of technology "rushed", and it led as pointed out by Sýkora to the creation of:

a joint declaration of several renowned biologists and bioethicists from various countries calling for a global (temporary) halt (moratorium) on experiments which would lead to the creation of genetically edited children. This halt on further experimentation is to "permit discussions about the technical, scientific, medical, societal, ethical, and moral issues that must be considered before germline is permitted" and "this period would provide time to establish an international framework" (Lander et al. 2019 [2019, 511-512]). 
In further continuations of this discussion, the voices and arguments of bioethicists (Mackellar 2019; Vijlbrief et al. 2020) can be heard. This article discusses one important postulate from these discussions: the restrictions on the use of technology used in "free"/"limited" art creation (Macneill and Ferran 2011).

Until the clinical use of CRISPR-Cas9, biotechnology was an internal matter for research institutions; however, the effective application of germline modification made it a "quintessentially public issue". In this context, it is necessary to place this technology in the public sphere and make scientific results accessible to the public within a public dialogue, while concurrently encouraging scientists to take responsibility for their research's effects on society (Vijlbrief et al. 2020). The Geneva Statement on Heritable Human Genome Editing describes the conditions of public dialogue in greater detail. It argues that the discussion must be public, global, and inclusive, and should not become dominated by the voices of scientists developing new technologies; instead, it should include experts from the fields of the social sciences and humanities, law, politics, and the wider circles of organized civil society and public institutions (Andorno, Baylis, Darnovsky et al. 2020).

Independent initiatives from academic societies have spoken out in favor of the transfer of such scientific information to the public through international networks and online presentations of research (Jasanoff and Hurlbut 2018). Simon Burall, an expert on dialogue between science and the public at the Citizens and Science program, recommended some methods on how to further the popularization of CRISPR technology among a broader audience. According to him, specific potential technological applications may be very controversial; therefore, national governments and decision-making parties should solve them with a "new engagement" whereby the public can influence the degree to which political leaders are informed and subsequently influence their political decisions. In the process of building a new engagement through public awareness and explaining the scientific foundations of gene editing, it would be advisable to use methods that have proven useful in prior recent innovations "through news stories, at science festivals, in public lectures and in museums" (2018, 438-439). From the perspective of science festivals, this "new engagement" is useful in explaining the practices relating to posthumanist aesthetics.

As an example, the "Introduction to Posthuman Aesthetics" (Leopoldseder, Schopf, and Stocker 2019, 247) project presents an application which permits experimentation across a broad spectrum of fields, supports the sharing of knowledge with the wider community, references the processes of the democratization of science, and supports methods of independent research in the form of DIY home experiments. Here the subject of creative work is more than just the human being; indeed, "the toolkits question the creativity of non-humans and do not presume humans to be the only creative force at work" (247). This direction of posthuman aesthetics casts doubt on "positive science", but it also redirects scientific activities to various societies and subjects - such as the "science citizen" and scientific knowledge of local and ethnographic groups and shamans - and it highlights the use of animals and machines in the scientific process (Domańska 2013, 24-26). Posthuman aesthetics focusing on the "I" (subject) as no longer holding the central position through which 
all is perceived and presented have not yet been confronted with the challenge to accept or implement a horizon of academic bioethics which would primarily - from a historical perspective in bioethical discourse - make reference to healthcare provision in poor material conditions. Bioethics thus searches for the meaning of the subject in the context of their abilities in the field of rational decision-making in situations of strong emotionality, ${ }^{1}$ while also considering social, political, and cultural commitments and restrictions (Botbol-Baum 2015).

\section{TRANSFERRING SCIENCE AND BIOETHICS TO THE PUBLIC}

How ready is the art world for the transfer of science and bioethics to the public? To answer this question, it is necessary to reference the reproduction of art media and artworks which reach into biotechnology and bioart as a means of expression. Over the past few decades, there has been a well-established opinion in academic and artistic practice that art has carved its way out of traditional art history disciplines and that the antiquated "techné" no longer avoids the sciences and modern technology. From a historical viewpoint, this can be seen as a paradigm shift most poignantly analyzed by the critic Arthur Danto ([1997] 2013); despite the contemporary backlash, he gave a philosophical context to art using items of convenience and new technologies such as the digital camera. Danto emphasized that since the mid-20th century, and with increasing regularity, projects were being created which grasped for means of expression outside traditional art media such as painting and sculpture. He suggested that for the history of Western European art, the search for an answer to the age-old philosophical quandary of "what is art" had lost its meaning. For these reasons, he perceived current art to belong to the category of "after the end of art" (1997). Instead of pursuing artistic values in the context of evolutionary changes and transformations, Danto proposed the image of a vascular bed containing various philosophically reasoned artistic objects, solutions, and activities. And thanks to this paradigm shift in the world of art, various art initiatives, and experiments were launched for the furthering of artistic methods and means in science and technology that could also be considered as artistic phenomena.

One example of these projects is EAT (Experiments in Art and Technology), which was founded in 1966 by the artists Robert Rauschenberg and Robert Whitman alongside the engineers Billy Klüver (Klüver and Martin 2003) and Fred Waldhauer; all of them were intrigued by the potential application of technologies in art. The main goal of EAT was to document the success rate of cooperation between artists and the scientists providing them with new materials, such as plastics, resin, video, electronic technology, and computers, which at that point were usually only available to research institutes. This organization allowed for experimentation with cutting-edge technologies such as chat links, cable televisions, faxes, lasers, and digital graphics. Indeed, Robert Rauschenberg's Oracle (1962-1965) sound sculpture was still being exhibited as of 2021. Similar initiatives focusing on digital art emerged concurrently in Europe, such as the Institut de Recherche et Coordination Acoustique/Musique in France (which was founded in 1969) and the Ars Electronica festival in Austria (which has been held since 1979). The annual reports from the festivals show how artists searched for means of expres- 
sion in electric and then electronic New Media, where ultimately the concept of biomedia developed. These media can be "wet", i.e., in some way "alive" - using live tissue and cells as "Live Art" (Bakke 2014) - or "transgenetic", meaning that they use the genetic information in live tissue or as the content for electronic information in a "live system". A more general name for this sort of artistic direction is simply "bioart".

In relation to the question of how the art world has prepared to transfer bioethics to the public, it is worth emphasizing that to this day there have been few projects that have directly reacted to the need to acquaint the public with bioethics; such works have mostly been focused on health, health care and similar areas. In this context, the relevant literature ${ }^{3}$ refers to the Art + Bioéthique project (Couture et al. 2017), which took place in Montréal and initiated cooperation between bioethicists, art historians and artists with the aim of expressing bioethics through arts and starting a public discussion on bioethical issues through the blending of arts and bioethics. Smaller events took place in the form of exhibitions, as well as a workshop and a platform that combined artworks, essays and cultural and scientific mediation activities directed at the general public as well as illness-support groups. Some authors refer to the difficulty of interdisciplinary communication between authors - bioethicists and artists - in order to achieve an artistic and bioethical consensus.

These projects and similar ones have used various media such as literature, ${ }^{4}$ film, visual arts, theater performances, and art workshops to present topics that highlight issues of the relationship between art and bioethics. The analysis of this relationship yields a relevance for both disciplines. For bioethics, the "experience of direct engagement", "direct involvement", and the familiarization with new discursive and narrative forms alongside the aesthetic values of art has been useful in balancing out the dominant features of bioethics (mind and rationality) (Macneill 2017; Chambers 2005). On the other hand, those limitations which, as regulatory and bioethical postulates (Vaage 2016a), dominate bioethicist discourse can inspire art discourse on a theoretical level (Macneill and Ferran 2011). This postulate debating "restrictions" in the practice of art was formed by the bioethicist Paul Macneill as part of the Art and Bioethics framework discussion at the World Congress of Bioethics in Singapore (Macneill and Ferran 2011). Ionat Zurr also meaningfully contributed to the discussion with her analysis of limitations "handed down" by the bioethics commission on art projects undertaken at SymbioticA (Zurr and Catts 2014), a laboratory established in 2000 at the School of Anatomy, Physiology, and Human Biology (now the School of Human Sciences) at the University of Western Australia which, according to the initiators, was focused on exploration and speculative research into the application of various biological and biotechnological tools and materials as a means for artistic expression (Zurr and Catts 2003).

\section{RESTRICTIONS AND LIMITATIONS ON BIOART}

The "limitations" from the ethics commission which Zurr referred to would be more accurately described as questions to the "ethics commission" regarding art research projects realized at the SymbioticA laboratory. Answers to the questions and their evaluation by the commission were part of the approval process for the imple- 
mentation of projects, making them accessible to the audience which is analogous to the approval process for scientific projects by Human Research Ethics Committee (HREC).

If we are to treat questions and answers ("limitations") as a crossroads between art and science from a bioethics perspective, we can identify two to three categories of issues. In the interest of clarity, these will be defined in reference to one of Stelarc's projects:

1. Safety checks for scientific projects: (a) securing raw materials (such as blood, cells, tissue, laboratory animals, and the artist's skin) and the question of whether this would be in line with regulations pertaining to research on humans and animals as well as regulations for acquiring cells and tissue; (b) determining the scientific contribution of the project in terms of improvement of research processes; and (c) determining the contribution for the furthering of understanding of the technology.

2. Safety checks for audiences exposed to exhibited projects: Stelarc's project of transplanting live cells (acquired in accordance with the rules) into an implant of biodegradable polymers, which created a quarter-scale replica of Stelarc's ear on his forearm; this was evaluated on ethical ${ }^{5}$ grounds of "when and why the audience should be protected" and whether "the integrity of the body was maintained." (Zurr and Catts 2014, 208).

The solution to the first issue was found with the assistance of the audience. The second issue was defended with reference to the "technology understanding" requirement, and the project showed the possibilities stemming from the manipulation of living systems and the fact that tissue can be kept alive even when apart from the human body.

3. The identification of non-scientific characteristics: this is analogous to the aesthetic function of a project or artwork. Stelarc's project was designed so that the audience would be encouraged to reconsider their preconceived notions of "living" systems and the perception of "life", using the context of the presented concept of "partial life": the replica of the ear. The audience was to reconsider what it meant to be alive. ${ }^{6}$ The project thus prepared the foundation for further philosophical and ethical aspects of discussions about life and being alive (Zurr and Catts 2014).

If we were to accept such a typology of "restrictions"/"limitations" on projects which are both artistic and scientific, the aesthetic function of a project or work may be linked to the "contribution for understanding technology" (209) which the project presents in the context of aesthetic categories and the theory of culture. Aesthetic categories would include "symbolic meanings", "irony", and the "grotesque" (209), and the theory of culture would include alternative bioethics (Zylinska 2009 and 2013) and discussions with the audience which, beyond simply transferring scientific knowledge (Vijlbrief et al. 2020; Burall 2018; Domańska 2013) would also invite the audience to alternative stances, the reconsideration of stereotypes, introspection, and a reflection on the bioethical aspects of technology presented in given bioartworks (Zurr and Catts 2014; Macneill 2017). 
When focusing on the aesthetic function of a project performed in a laboratory - indeed, "on the edge of biology", a description suggested by Nora Vaage (2016b) - multiple questions emerge: is the author of the artwork an individual or a collective? Are the scientists and/or bioethicists co-authors? (One can find analogous discussions in the field of digital art.) To what degree is it important to differentiate between the medium (carrier) and the used technology and laboratory equipment (the medium tool)? How can we identify the bioartwork's aesthetic function ( $\mathrm{Mu}-$

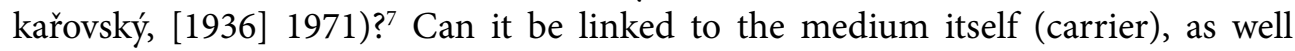
as the techné, that is, the methods of application of particular tools according to laboratory processes (device), and ultimately the information channel (when the artist explains in discursive form the "operation" and meaning of the project)? (Macneill and Ferran 2011) (Presently, bioart conceived of in such a way is consequently labeled "hybrid art".) Does the aesthetic function have to be connected with the conceptual "use" of both scientific knowledge as well as biomedia? (This is often posited when discussing the vanishing border between art and science.) Must the artistic intention of the author be kept in mind? And how does the artistic intention differ from the scientific intention of a project? These questions can only be partially answered by bioart publications. A more thorough analysis may provide the foundation for a further elaboration on relationships between the aesthetic function of a project and its scientific contribution, and consequently the evaluation of a bioart project. That, however, is beyond the scope of this article.

Since 2000, when the first biophysics laboratory (SymbioticA) opened up to artistic initiatives, the process of perception and the sensitivity to bioethics have deepened in multiple directions. In terms of the process of the creation of bioart, the process of cooperation between science institutions (which provide technology) and the procedures of making projects accessible to the public in galleries (as a part of public ethics) and at science festivals have developed to a point where they are a conduit of science to the audience and public at large (Hiebert 2017). In the decade since the World Congress in Singapore, the presence of bioethics perspectives on bioart projects has become more precisely articulated, as is apparent from safety requirements at events and festivals such as Ars Electronica (Zawojski 2015), the exhibition areas of MoMa (Aristarkhova 2010), and most recently at the "Art's Work/Genetic Future" exhibition and in the dedication in its catalog. The exhibition's organizers (North Carolina State University) and the curator Hannah Star Rogers (2019) presented works dedicated to the genetic future of artworks as a set of works ranging from those created with traditional media up to projects on "art about ethics in the genomic age" (Mulligan 2019).

Presently, hundreds of artists across the globe are working with living material and creating "living artworks" (Vaage 2016b), ${ }^{8}$ hybrid art, and "bioart" (Macneill and Ferran 2011). All these projects fall under the definition of bioart:

Bioart, in the strict sense, is a very young and ethically controversial form of art, which works with live tissues, bacteria and living organisms; in the broad sense, it might include artists who address biotechnology merely from a symbolic or conceptual perspective. The connection between Posthumanism and bioart is complex (Ferrando 2016, 7). 
Multiple bioartworks have been created in connection with CRISPR technology on both the symbolic and conceptual levels; two such projects include "Genetics Gym" and "Made Do and Mend". Directly in response to the clinical application of CRISPR by Jiankui, the British artist and designer Adam Peacock created the "Genetics Gym" project. It was exhibited at the Science Gallery in Melbourne in 2018 and asked the question "Would you CRISPR your genes?" 9 The fact that the use of gene-editing permits for a world where individuals would be able to modify their DNA at will (Murillo 2018) is relevant to the art world, and is even "distressing", according to Peacock. ${ }^{10}$ The "Genetics Gym" project was presented by Peacock in opposition to efforts by transhumanists to influence the transformation of humanity and the freedom to decide on one's own bodily appearance. Peacock looks at the issue of marketing strategies within social media sites and advertising, which will expose people to the risk of unknown yet predictable interests and offers from the bio-business sector (Hiebert 2017, 7).

In this regard, today's design strategy, based on a principle of ignoring all standards for the treatment of boundaries and traditions, must make a shift toward responsibility. If gene-editing technology really was to provide possibilities for the implementation of fantasies of unlimited human bodily designs, such as the disharmonious forms suggested at "Genetics Gym", the question arises as to what sort of psychological, legal, and ethical preparations would have to be made in order to prepare today's humans for such developments. Can we solve the question of human autonomy when confronted with gene marketing? These questions are relevant for both transhumanist art as well as bioethics (Porter 2017, 237).

The "Make Do and Mend: Exploring Gene Regulation and CRISPR" project is the result of Anna Dumitriu's longstanding work at "The Future Emerging Art and Technology" project, where she had the opportunity to learn to understand the decoding of genes:

The lab is the lead coordinator on the MRG-Grammar project, which aims to devise a new strategy for deciphering the rules of gene regulation. Using synthetic biology, DNA synthesis and high-throughput analysis, the project aims to generate new types of biological datasets that systematically explore all possible regulatory landscapes (Dumitriu and Godlberg 2019, 1).

"Make Do and Mend" conceptualizes an event in the history of medicine (the discovery of penicillin at Oxford in the precarious conditions of the World War II) as well as rationing, regulations on the use of basic products during the Battle of Britain, and government encouragement to repair and re-use old clothes by using the phrase "make do and mend", which an artist and a scientist integrated into the genetic code of a bacteria with "damaged" resistance to antibiotics. With assistance from Sarah Goldberg and Roee Amit as well as the artists, Dumitriu mended a hole in a military uniform which had been distributed in 1943 by the War Production Board with a decorative stitch and special thread. The thread was created from E. Coli bacteria modified using CRISPR-Cas9. The artist learned to practically use CRISPR-Cas9, which was a time-intensive and highly demanding tool in terms of precision: 
I worked hands-on to edit the genome of the TOP10 E. coli strain to remove an ampicillin (a penicillin-related antibiotic) resistance gene which was part of the bacterium's genome, having previously been inserted into it using CRISPR-Cas9, literally mending the bacterium in the same way that the dress is mended with the bacteria-stained cloth (Dumitriu and Goldberg 2019, 1).

On the conceptual level, this was the use of cutting-edge technology to "repair" an organism (E. coli bacteria) so that it would revert back to its state before 1941, when penicillin had only just begun to save human lives. This is a symbolic gesture, because the $E$. coli that was available to the project was evolutionarily distant to the 1941 version. Dumitriu's intention was to evoke images of potential possibilities that technologies such as CRISPR could bring, especially in terms of "mending" problems which scientific research failed to predict; there is analogy here with antibiotic-resistant bacteria. Conversely, technology will only bring further "unexpected issues" (Dumitriu and Goldberg 2019). This familiarization with CRISPR gene-editing technology had the intention of producing a project which would be able to speak to a wide spectrum of audiences at workshops using a historical parallel and the context of the evolution of bacteria, alongside friendly and comprehensible language, in order to expand scientific knowledge among the general public about CRISPR-Cas9 gene editing and allow for an open discussion about what sorts of communication channels can deliver information about scientific progress to the public and how this affects their decision-making in specific situations. The potential of technologies such as CRISPR-Cas9 and the voices of bioethicists "to consider its use" is an attractive philosophical concept for an interpretation and possible understanding of bioart projects, which have been created in a world where biotechnological and biomedical offers and marketing are present.

\section{BIOART AS AN ETHICALLY CONTROVERSIAL PHENOMENON}

When discussing these artistic activities, the question arises as to why the "connection between posthumanism and bioart is complex" and why bioart is "ethically controversial" (Ferrando 2016). Bioart has a postmodernist strategy of leveling out borders and rejecting referential relationships in areas such as literary genres and forms, musical genres and the arrangement of musical texts for new instruments, multi-genre theater, the blurring of boundaries between text and image, and the blurring of boundaries of epistemology, ontology, and similar areas. Digital technologies in communication and software have opened an interesting field of activity for this trend and have significantly influenced the development of information sciences and the natural sciences, spectacularly so in the development of molecular biology, genetics, and medicine. The coding languages that have provided the possibilities for intersemiotic coding (Szczęsna, Pisarski, and Kubiński 2019) as well as the generation of new content from digital information (e.g., generative poetry and code poetry) and sound visualization have also brought about the development of software and computer systems within works by the first bioartists, such as in the form of hacking and biohacking. The empirical yet well-described process of the development of activism and bioart (Sützl and Hug 2012) was con- 
firmed by the first bioart project in the USA by Jonas Davis, "Microvenus" (1986), a pictogram - similar to the Germanic symbol of life and earth - showing the insertion of a genetic sequence into E. coli bacteria. Among other things, this work conceptually illustrated the potential of storing and encoding data in resistant bacteria as a visual and biological carrier.

The leveling out of boundaries as a theoretical concept is ethically ambivalent in terms of the relationship of bioart toward environmental policies, because it can justify the unrestricted misuse of natural resources by mankind (Ferrando 2016). This ethical ambivalence, which refers to the possibility of strengthening the position of the subject, complicates the importance of bioart within posthumanism; however, if the projects by female artists mentioned by Ferrando were supplemented by projects from male artists, such as GenTerra, Free Range Grain, and the activists of the Critical Art Ensemble (Sützl and Hug 2012), it would become apparent that environmental policies refer to spaces of biopower and bio-business (e.g., the sale of genetically modified seeds, bio-pharmacological products, military biotechnology, and biometers), which is also a part of posthumanism, as was suggested by Michel Foucault $(2000,116)$. In this context, however, a question still remains as to what the relationship of bioethics is toward controversial projects carried out as a part of bio-activism: for example, what does one make of the Critical Art Ensemble's "bioterrorist" experiment to alert consumers to the presence of genetically modified foods in their diets? And what about the Tactical Bioart project, aimed at creating a new science where art cooperates with activism, animal husbandry, and chemistry? (Sützl and Hug 2012).

From the beginning, "body art" has aroused ethical controversy and penetrated into bioethical discourse over time (Chambers 2005). Bioart is recognized as either being ethically significant (Zurr and Catts 2014) or controversial (Ferrando 2016). There are several reasons for this, which can be summarized in two areas that relate to (1) the conditions for creating a project and (2) the contextualization of projects through philosophy or aesthetics:

1. a: They are created with the intention to expose the violence of power (Dumit 2008), or they are part of the activity of anarchist groups and are intentionally provocative, such as in the case of the Critical Art Ensemble (Sützl and Hug 2012) and Eduardo Kac (Ferrando 2016; Vaage 2016a).

b: They concern experimentation with one's own body. For instance, Orlan's and Stelarc's projects evoke ethical issues concerning aesthetic surgery, tissue surgery, and orthopedics, and they are controversial from the point of view of medical bioethics in terms of there being damage done to a healthy body (Macneill and Ferran 2011).

c: They originate in laboratories (Zurr and Catts 2014), or living bodies, or animals are involved; see K. D. Thornton, Zaretsky, and Kathy High (Aristarkhova $2010,5)$. Also the animal species which are ecological predators in some regions yet which are genetically modified so that they do not reproduce (e.g., the gene drive machine). 
d: They are based on gene editing (CRISPR technology) and are presented in the context of a new concept of neo-eugenics (see the catalog of the "Art's Work/Genetic Futures" exhibition).

2. a: In the interpretations of some artists (Zaretsky) or cultural theorists (Zylinska 2009 and 2014), bioartworks are ethically problematic due to "bioethics" itself, which they present primarily in a theological context. One of the implications is the meeting of the theological conception of "life" as a "sacred value" with the vitalist idea of the "continuum of life" and the "current of life." This confrontation unwittingly leads to unlimited artistic creativity and invention, which is guaranteed and supported in bioart by the concept of vitalism (Zylinska 2014, 199).

$\mathrm{b}$ : In the relevant literature, there is often a general premise to separate ethics and aesthetics from one another instead of combining them, with reference being made to the famed artistic promoter of Nazism, the director Leni Riefenstahl (Devereaux 1998). Recently, Vaage (2016a) and Macneill (2017) tried to comprehend the relationship between ethics and aesthetics by returning to the concepts of the ethical aspect of (beautiful) art.

\section{“TRUST ME, I'M AN ARTIST": TOWARDS AN ETHICS OF ART/ SCIENCE COLLABORATION}

"Trust Me, I'm an Artist" was an important project that was implemented from 2011 to 2014 as part of the Horizon 2020 program within the context of the EU's decision on the regulation of genetic research. The project was designed by Anna Dumitriu in long-term collaboration with the microbiologist John Paul and the bioethicist Bobbie Farsides and the Waag Society (Institute for Art, Science, and Technology in Amsterdam) with the aim of examining ethical issues within the cooperative process of art, science, and biomedicine. After the artists' experience when facing the requirements of the ethics committee (Zurr and Catts 2015) and the complicated bioethical nature of works of bioart (Francesca Ferrando, Nora S. Vaage, Paul Macneill, and Tod Chambers), it seemed clear that the time had come to examine bioethics and the implications of artistic work in laboratories and of bioartists in particular (Dumitriu and Goldberg 2019). The project was carried out in several stages (a questionnaire for artists, the presentation of projects based on an approval process by ethics committees, an invitation to public discussions, and guiding the public in creating separate DIY projects) and in galleries that work with scientific institutes (Arts Catalyst in London, CIANT in Prague, the Kapelica Gallery in Ljubljana, and Medical Museion in Copenhagen) along with the participation of artists, curators, and the public. Based on questions given to artists related to, among other things, their degree of readiness to subordinate their artistic intent or artistic freedom to scientific purposes, and conversely; to carry out a project even if it would not lead to any scientific results, the authors of the project tried to create a model upon the basis of which specific projects could be assessed in terms of public ethics (Hiebert 2017, 1). In this context, Anna Dumitriu and Bobbie Farsides have formulated the need to adopt certain regulations and manage approaches to artwork as a current challenge for artists working with 
scientists at the forefront of innovation, who are pushing the boundaries of what they talk about and how they do so (2017).

Approaching scientific and intellectual boundaries in artwork should, according to those behind the "Trust Me, I'm an Artist" project, encourage artists to actively address the ethical and philosophical challenges that science and new technologies pose to society. When looking at the challenges of bioethics, it is therefore necessary for artists to "consider the use" of a particular technology and think about how and for what artistic purpose they plan to use it, while also taking into consideration how it can affect society.

The "Trust Me, I'm an Artist" project confirmed that "ethics committees" could take into account the specifics of works of art, and it leaned toward the view that art projects do not bring direct scientific benefits (Zurr and Catts 2014, 212). Nonetheless, they can lead scientific and technological collaborators toward creating a new ethical framework where they can work with active players from the world of art (Dumitriu and Farsides 2017, 2). The aim of "Trust Me, I'm an Artist" was to stimulate new ways of thinking about how art, biotechnology, and biomedicine can intersect in the creation and survival of new art forms.

The "consideration of the use" of a specific process of project implementation refers to the idea of "limited" artistic freedom; it evokes the existence of some imaginary or real boundaries for bioart. It would be nice to believe that the specific boundaries of today's bioart, which has emerged in an age of rapidly evolving biotechnology (and CRISPR gene editing) concern "art about ethics in the genomic age"). As an example, the Lucy Mice project by Joe Davis, which was prepared for the Art's Work/Genetic Futures event in 2020, was discussed in advance with the Commission for the Treatment of Animals in Research; among other things, it focused on the bioethics of a random genetic mutation of the "happiness gene" in the examined mice. A few countries, such as Australia, support the acquisition of the critical awareness of ethics in university education in the artistic (creative) disciplines, and they are preparing students to discuss ethical issues in both their research and artistic work (MacNeill et al. 2020).

\section{CONCLUSION}

One of the roles of art in communities using biotechnology will be that of mediation between science producers, technological applications (focused on clinical use, marketing, and AI), and the public. The biotechnology and living biological material used in the work of bioartists are sorts of models and experiments that evoke bioethical problems that society will have to resolve within different communities (e.g., scientists, producers of technologies and applications, different user communities, artists, activists, public organizations, and institutions). DIY strategies practiced within the aesthetics of posthumanism provide models for solving community problems and are also suitable for obtaining and transferring information to the public and exercising practices that lead to public discussion. An analysis of the conditions and various aspects of the "use" of biotechnology in art has shown that bioart has great potential for public discussions focused on the bioethical aspects of technology. However, it is questionable how they are used in mediatization practices, various media, curatorial practices, exhibition halls, and possibly also in political negotiations. 


\section{NOTES}

1 In the environmental humanities, the reconceptualization of the posthuman subject has been urged by Ewa Domańska $(2013,31)$; in a parallel sense, the reconceptualization of rationality as a component of bioethics through the lens of its relationship to aesthetics has been postulated by Paul Macneill (2017).

2 "In the area that has become known as bioart there is a strong blurring of boundaries between art and the biosciences to create forms of hybrid practice. Bioart is a form of art practice that engages in some way with biology. It involves living organisms, living tissues, bacteria and cell biology and employs, considers and critically reflects on the ethics, methods and practices of biotechnology or biomedicine" (Dumitriu and Farsides 2017, 4).

3 It is apparent that the undertaking of artistic projects focusing on topics of bioethics is not evenly distributed on a global scale. According to the relevant literature, such projects tend to be found in Australia, Canada, England, and Singapore. The correlation between the emergence of such projects and the operation of independent national structures of bioethics is a question that sociologists, political scientists, and cultural studies scholars could consider answering.

4 Narrative bioethics. See Murray 1997.

5 It was not assessed from a biomedical point of view, such as in the context of aesthetic surgery or that of diagnosis in terms of voluntary harm being done to one's own body.

${ }^{6}$ Compare with an opera about post-human life and death: Death and the Powers (composed by Tod Machover and developed at the MIT Media Lab along with Diane Paulus - director - and Alex McDowell - production designer).

7 "The aesthetic function is defined paradoxically as a function denying the (usual) functionality - either as the function allowing for the mediation among all the functions or among all layers of the (given) material, or as the medium in its most fundamental social and anthropological purposes. Out of many attempts, the most productive is still Jan Mukařovskýs attempt to grasp the aesthetic function as a mediation function which determines the relation between functions - and values - which are only very difficult to combine in a broader social reality" (Müller, Chudý et al. 2019, 651).

8 It is not yet clear how the bioart community as a whole has reacted to the call for a "temporary embargo" on using CRISPR technology on the human germline genome. In this sense, the work of Stelarc has most directly dealt with the issue: "The problem is that it goes beyond mere Cosmetic Surgery. It is not simply about the modifying or the adjusting of existing anatomical features (now sanctioned in our society), but rather what's perceived as the more monstrous pursuit of constructing an additional feature that conjures up either some congenital defect, an extreme body modification or even perhaps a radical genetic intervention (Macneill and Ferran 2011, 79).

9 https://melbourne.sciencegallery.com/perfection-exhibits/genetics-gym-ss18. Melbourne's Science Gallery poses this question on the webpage of the "Genetics Gym" project.

10 "It becomes alarming because the more I work with this, and the more I speak with geneticists we start to realize that some of what I'm speculating is not just possible, but is fast becoming a reality, and it comes with a sense of urgency to discuss how we want this technology to be developed" (Kamau 2018).

\section{LITERATURE}

Andorno, Roberto, Françoise Baylis, Marcy Darnovsky et al. 2020. "Geneva Statement on Heritable Human Genome Editing: The Need for Course Correction." Science and Society 38, 4: 351-354. DOI: https://doi.org/10.1016/J.TIBTECH.2019.12.022.

Aristarkhova, Irina. 2010. "Hosting the Animal: The Art of Kathy High." Journal of Aesthetics and Culture 2, 1: 1-12. DOI: https://doi.org/10.3402/jac.v2i0.5888.

Bakke, Monika. 2014. "Practicing Aesthetics Among Nonhuman Somas in the Age of Biotech." In Practicing Pragmatist Aesthetics: Critical Perspectives on the Arts, ed. by Wojciech Małecki, 153-168. Leiden: Brill. DOI: https://doi.org/10.1163/9789401210812_012. 
Bolter, Jay David. 2016. "Posthumanism." In The International Encyclopedia of Communication Theory and Philosophy, ed. by Klaus Bruhn Jensen and Robert T. Craig, 1-8. Hoboken, NJ: John Wiley \& Sons. DOI: 10.1002/9781118766804.wbiect220.

Bostrom, Nick. 2002. "Existential Risks: Analyzing Human Extinction Scenarios and Related Hazards." Journal of Evolution and Technology 9, 1: 1-31.

Bostrom, Nick. 2008. "Why I Want to be a Posthuman When I Grow Up." In Medical Enhancement and Posthumanity, ed. by Bert Gordijn and Ruth Chadwick, 107-137. Dordrecht: Springer. DOI: https:// doi.org/10.1007/978-1-4020-8852-0_8.

Botbol-Baum, Mylène. 2015. "Epistemology of Bioethics in the Making: From Historical Context to Conceptual Plurality and Anticipation." Bioethics Update 1, 2: 79-95. DOI: https://doi. org/10.1016/j.bioet.2015.12.002.

Burall, Simon. 2018. "Rethink Public Engagement for Gene Editing." Nature 555: 438-439. DOI: https:// doi.org/10.1038/d41586-018-03269-3.

Chambers, Tod. 2005. “The Art of Bioethics." Hastings Center Report 35, 2: 3. DOI: 10.1353/hcr.2005.0018.

Couture, Vincent, Jean-Christophe Bélisle-Pipon, Marianne Cloutier, and Catherine Barnabé. 2017. "Merging Arts and Bioethics: An Interdisciplinary Experiment in Cultural and Scientific Mediation." Bioethics 31, 8: 616-630. DOI: https://doi.org/10.1111/bioe.12391.

Danto, Arthur C. [1997] 2013. Po końcu sztuki. Sztuka wspótczesna i zatarcie się granicy tradycji [After the End of Art: Contemporary Art and the Pale of History]. Trans. by Małgorzata Sugiera. Kraków: Universitas.

Devereaux, Mary. 1998. "Beauty and Evil: The Case of Leni Riefenstahl's Triumph of the Will." In Aesthetics and Ethics: Essays at the Intersection, ed. by Jerrold Levinson, 227-256. Cambridge: Cambridge University Press. DOI: https://doi.org/10.1017/CBO9780511663888.009.

Domańska, Ewa. 2013. "Humanistyka ekologiczna." Teksty Drugie 139-140, 1-2: 13-32.

Dumit, Joseph. 2008. "Foreword: Biological Feedback." In Tactical Biopolitics: Art, Activism and Technoscience, ed. by Beatriz Da Costa and Kavita Philip, xi-xiv. Cambridge, MA and London: The MIT Press.

Dumitriu, Anna, and Bobbie Farsides, eds. 2017. Trust Me, I am an Artist: Towards an Ethics of Art and Science Collaboration. London: Blurb.

Dumitriu, Anna, and Sarah Goldberg. 2019. "Make Do and Mend: Exploring Gene Regulation and CRISPR through a FEAT (Future Emerging Art and Technology) Residency with the MRG-Grammar Project." Leonardo 52, 1: 66-67. DOI: https://doi.org/10.1162/leon_a_01466.

Farsides, Bobbie, Anna Dumitriu, and Annick Bureaud. 2016. “Trust Me, I’m an Artist." Leonardo 49, 3: 262-263. DOI: https://doi.org/10.1162/LEON_a_01272.

Ferrando, Francesca. 2016. "A Feminist Genealogy of Posthuman Aesthetics in the Visual Arts." Palgrave Communications 2, art. Nr 16011: 1-12. DOI: https://doi.org/10.1057/palcomms.2016.11.

Ferrando, Francesca. 2019. Philosophical Posthumanism. London: Bloomsbury Academic.

Foucault, Michel. 2003. "Truth and Power." In Power: Essential Works 1954-1984, ed. by James D. Faubion, trans. by Robert Hurley, 111-152. London: Penguin.

Gladden, Matthew E. 2019. "Who Will be the Members of Society 5.0? Towards an Anthropology of Technologically Posthumanized Future Societies." Social Sciences 8, 5: 148. DOI: https://doi. org/10.3390/socsci8050148.

Guertin, Carolyn. 2012. "Mobile Bodies, Zones of Attention, and Tactical Media Interventions." In Activist Media and Biopolitics: Critical Media Interventions in the Age of Biopower, ed. by Wolgang Sützl and Theo Hug, 17-28. Innsbruck: Innsbruck University Press.

Hayles, N. Katherine. 2011. "Wrestling with Transhumanism." In Transhumanism and its Critics, ed. by Gregory R. Hansell and William Grassie, 215-226. Philadelphia, PA: Metanexus Institute.

Hern, Alex. 2019. "New AI Fake Text Generator May Be Too Dangerous to Release, Say Creators." The Guardian February 14, 2019. Accessed February 15, 2021. https://www.theguardian.com/technology/2019/feb/14/elon-musk-backed-ai-writes-convincing-news-fiction.

Hiebert, Ted, ed. 2017. Naturally Postnatural - Catalyst: Jennifer Willet. London: Noxious Sector Press. Hussain, Zareena. 2000. "Science as Art Unites Disciplines: Artists Use Microbiology as a Medium for Art." The Tech 120, 26. http://tech.mit.edu/V120/N26/bioartists.26f.html.

Huxley, Julian. 1957. New Bottles for New Wine. London: Chatto and Windus. 
Jasanoff, Sheila, and J. Benjamin Hurlbut. 2018. "A Global Observatory for Gene Editing." Nature March 21, 2018. Accessed February 15, 2021. https://www.nature.com/articles/d41586-018-03270-w?mc cid=d9f0ddd816\&mc_eid=822a149de0.

Kamau, Sebastian. 2018. "Adam Peacock, Tackling Consumer Psychology through Genetic Design." Clotmag.com. Accessed January 15, 2021. www.clotmag.com/design/adam-peacock.

Koepsell, David. 2017. "In Art We Trust?" In Trust Me, I am an Artist: Towards an Ethics of Art and Science Collaboration, ed. by Anna Dumitriu and Bobbie Farsides, 71-77. London: Blurb.

Klüver, Billy, and Julie Martin. 2003. EAT - The Story of Experimensts in Art and Technology 1960-2001. Tokyo: NTT InterCommunication Center.

Lander, Eric S., Françoise Baylis, Feng Zhang, Emmanuelle Charpentier, Paul Berg, Catherine Bourgain, Friedrich Bärbel, J. Keith Joung, Jinsong Li, David Liu, Luigi Naldini, Jing-Bao Nie, Renzong Qiu, Bettina Shcoene-Seifert, Geng Shao, Sharon Terry, Wensheng Wei, and Ernst-Ludwig Winnacker. 2019. "Adopt a Moratorium on Heritable Genome Editing." Nature 567 (7747): 165-168. DOI: https://doi.org/10.1038/d41586-019-00726-5.

Leopoldseder, Hannes, Christine Schöpf, and Gerfried Stocker, ed. 2019. Out of the Box. The Midllife Crisis of the Digital Revolution - Ars Electronica 2019. Berlin: Ars Electronica and Hatje Cantz.

MacKellar, Calum. 2019. "Genome Modifying Reproductive Procedures and Their Effects on Numerical Identity." The New Bioethics 25, 2: 121-136. DOI: 10.1080 / 20502877.2019.1606150.

MacNeill, Kate, Barbara Bolt, Estelle Barrett, Megan McPherson, Marie Sierra, Sarah Miller, Pia Ednie-Brown, and Carole Wilson. 2020. "An Ethical Engagement: Creative Practice Research, the Academy and Professional Codes of Conduct." Research Ethics 17, 1: 73-86. DOI: https://doi.org/10.1177/1747016120915950.

Macneill, Paul. 2014. "Ethics and the Arts: A Critical Review of the New Moralisms." In Ethics and the Arts, ed. by Paul Macneill, 167-178. Dorddrecht: Springer. DOI: https://doi.org/10.1007/978-94-017-8816-8_15.

Macneill, Paul. 2017. "Balancing Bioethics by Sensing the Aesthetic." Bioethics 31, 8: 631-643. DOI: https://doi.org/10.1111/bioe.12390.

Macneill, Paul Ulhas, and Bronac Ferran. 2011. "Art and Bioethics: Shifts in Understanding Across Genres." Journal of Bioethical Inquiry 8, 1: 71-85. DOI: https://doi.org/10.1007/s11673-010-9279-6.

Mukařovský, Jan. [1936] 1971. "Estetická funkce, norma a hodnota jako sociální fakty." In Studie z estetiky, ed. by Květoslav Chvatík, 7-65. Praque: Odeon.

Mulligan, Patti. 2019. "Curating Art and Science: Art's Work in the Age of Biotechnology." The Genetic Engineering and Society Center. Accessed January 10, 2021. https://research.ncsu.edu/ges/2019/03/ curating-art-and-science-arts-work-in-the-age-of-biotechnology/.

Murillo, Federikke. 2018. “Genetics Gym: Designing the Perfect Human.” Sublime Magazine. Accessed January 10, 2021._https://frederikkemurillo.com/genetics-gym-designing-the-perfect-human/.

Murray, Thomas H. 1997. "What We Mean by 'Narrative Ethics." Medical Humanities Review 11, 2: 44-57. Müller, Richard, Chudý Tomáš et al. 2020. Za obrysy média. Literatura a medialita. Praha: Karolinum.

Porter, Allen. 2017. "Bioethics and Transhumanism." Journal of Medicine and Philosophy 42, 3: 237-260. DOI: https://doi.org/10.1093/jmp/jhx001.

Rosenberg, Scott. 2017. "Why AI is Still Waiting for its Ethics." Wired.com. https://www.wired.com/ story/why-ai-is-still-waiting-for-its-ethics-transplant/.

Simoniti, Vid. 2019. "The Living Image in Bio-Art and in Philosophy." Oxford Art Journal 42, 2: 177196. DOI: https://doi.org/10.1093/oxartj/kcz007.

Sorgner, Stefan Lorenz. 2010. "Beyond Humanism: Reflections on Trans- and Posthumanism." Journal of Evolution and Technology 21, 2: 1-19.

Sützl, Wolfgang, and Theo Hug. 2012. "Introduction." In Activist Media and Biopolitics: Critical Media Interventions in the Age of Biopower, ed. by Wolfgang Sützl and Theo Hug, 7-17. Innsbruck: Innsbruck University Press.

Sýkora, Peter. 2019. "K posthumánnemu človeku prostredníctvom editovania génov pre kognitívne schopnosti." Filozofia 74, 7: 511-529. DOI: https://doi.org/10.31577/filozofia.2019.74.7.1.

Szczęsna, Ewa, Mariusz Pisarski, and Piotr Kubiński. 2019. "Strategies for the Creation of Meaning in Digital Art." In Remediation: Crossing Discursive Boundaries. Central European Perspective, ed. by Bogumiła Suwara and Mariusz Pisarski, 251-269. Berlin: Peter Lang.

Star Rogers, Hanah. 2019. "What Artists Offer: Shaping Our Genetic Futures." In Catalog Art's Work in the Age of Biotechnology: Shaping Our Genetic Futures, ed. by Hannah Star Rogers and William Myers, 26-43. Charlotte, NC: University of North Caroline Press. 
Toffoletti, Kim. 2007. Cyborgs and Barbie Dolls: Feminism, Popular Culture and the Posthuman Body. London and New York, NY: I.B. Tauris.

Vaage, Nora S. 2016a. “What Ethics for Bioart?” Nanoethics 10, 1: 87-104. DOI: https://doi.org/10.1007/ s11569-016-0253-6.

Vaage, Nora S. 2016b. Amplifying Ambiguities: Art on the Fringes of Biotechnology. Dissertation Thesis. University of Bergen. Accessed January 15, 2021. https://bora.uib.no/bora-xmlui/bitstream/handle/1956/12674/dr-thesis-2016-Nora-S-Vaage.pdf?sequence=1\&isAllowed=y.

Vijlbrief, Boy, Sam Riedijk, Diewertje Houtman, and Robert Hofstra. 2020. "Germline Genome Editing: Public Dialogue is Urgent but not Self-evident." European Journal of Human Genetic 28, 1: 4-5. DOI: https://doi.org/10.1038/s41431-019-0474-6.

Vita-More, Natasha. 2018. Transhumanism: What Is It? New Providence, NJ: Bowker Press.

Zawojski, Piotr. 2015. "Rzeczywistość bio-techno-logiczna. Dylematy sztuki i kultury w czasach posthumanizmu i transhumanizmu." In Bio-Techno-Logiczny Świat. Bio art oraz sztuka technonaukowa w czasach posthumanizmu i transhumanizmu, ed. by Piotr Zawojski, 270-288. Szczecin: 13muz/Instytucja Kultury Miasta Szczecin.

Zurr, Ionat, and Oron Catts. 2003. “Are the Semi-Living Semi-good or Semi-evil?” Technoetic Arts 1, 1: 47-60. DOI: https://doi.org/10.1386/tear.1.1.47/0.

Zurr, Ionat, and Oron Catts. 2014. "The Unnatural Relations between Artistic Research and Ethics Committees: An Artist's Perspective." In Ethics and the Arts, ed. by Paul Macneill, 201-210. Dorddrecht: Springer. DOI: https://doi.org/10.1007/978-94-017-8816-8_18.

Zylinska, Joanna. 2009. Bioethics in the Age of New Media. Cambridge, MA: The MIT Press.

Zylinska, Joanna. 2013. "Bioetyka inaczej, czyli o tym, jak współżyć z maszynami, ludźmi i innymi zwierzętami.” Teksty Drugie 139-140, 1-2: 154-172.

Zylinska, Joanna. 2014. “Taking Responsibility for Life: Bioethics and Bioart.” In Ethics and the Arts, ed. by Paul Macneill, 191-200. Dorddrecht: Springer. DOI: 10.1007/ 978-94-017-8816-8_17.

\title{
Toward a bioethical perspective for posthumanist aesthetics: Bioart as an example
}

Natural human. Posthuman aesthetics. CRISPR bioethics. Bioart. Anna Dumitriu. SimbioticA. Biohacking. Citizens and Science program.

The recent use of gene editing technology (CRISPR-Cas9) in clinical practice revived not only bioethical discussions surrounding the potential abuse of the technology, but also the democratization processes when making decisions about how biotechnologies are to be used. Biological material and laboratory techniques have served as means of artistic expression for several decades. Using the examples of bioart projects, this article will present to what extent and in what conditions could bioethics penetrate the aesthetic space of posthumanism - including DIY strategies as a mode of transfer of scientific and technological knowledge to the public, while engaging the people's participation in the decisions made concerning the future of the human genome.

\author{
Mgr. Bogumiła Suwara, PhD. \\ Institute of World Literature \\ Slovak Academy of Sciences \\ Dúbravská cesta 9 \\ 84104 Bratislava \\ Slovak Republic \\ bsuwara@gmail.com
}

ORCID ID: https://orcid.org/0000-0002-8000-1833 